\title{
Preparation and Characterization of an Eco-Friendly Polymer Electrolyte Membrane (PEM) Based in a Blend of Sulphonated Poly(Vinyl Alcohol)/ Chitosan Mechanically Stabilised by Nylon 6,6
}

\author{
Paula Nunes de Oliveira ${ }^{a}$, Adélio Miguel Magalhães Mendes ${ }^{a}$ \\ ${ }^{a}$ Laboratory for Process Engineering, Environment, Biotechnology and Energy - LEPABE, Department \\ of Chemical Engineering - DEQ, Faculty of Engineering, University of Porto, Portugal
}

Received: May 19, 2016; Accepted: June 24, 2016

\begin{abstract}
Membranes for fuel cell applications were prepared using two polymer blends: poly(vinyl alcohol) (PVAL) and chitosan (CS), 80/20 (w/w) and 60/40 (w/w) with and without nylon. Sulfosuccinic acid (SSA) was used both as a crosslinking and a sulfonating agent. An increasing in the SSA content raised ionic exchange capacity and consequently proton conductivity in the membranes. The addition of nylon has improved membrane mechanical properties by decreasing stiffness. Membranes presented good proton conductivity (around $10^{-2} \mathrm{~S} \mathrm{~cm}^{-1}$ ) and lower $\mathrm{H}_{2}$ and methanol permeability rather than the standard membrane Nafion ${ }^{\circledR} 115$. Membranes which showed to be stable under fuel cell operation were tested using hydrogen and methanol fuels. Membrane PVAL:CS, 80/20 (w/w), containing SSA crosslinker, (PVAL+CS)/SSA, of 4/1 ( $\mathrm{mol} / \mathrm{mol})$, has shown the best performance under fuel cell environment. However, results have shown that an improvement is required in the adhesion between the membrane and the electrodes.
\end{abstract}

Keywords: Fuel cell, Poly(vinyl alcohol), Chitosan, Nylon, Polymer electrolyte membrane (PEM)

\section{Introduction}

Polymer electrolyte membrane (PEM) is an important component in many electrochemical devices. In PEM fuel cells, polymer electrolyte membrane allows the permeation of protons from the anode to the cathode, preventing also anode/ cathode electronic direct contact. The most commonly used membrane in PEM fuel cells is a perfluorinated membrane, Nafion $^{\circledR}$, developed by DuPont. ${ }^{1}$ However, this membrane presents some limitations, such as low ionic conductivity at low humidity, susceptibility to degrade at high temperatures and high cost. ${ }^{2}$

Several polymers used to produce PEM have been researched as alternatives to replace Nafion; among them, cost-effective and environmental-friendly polymer electrolytes can become promising substitutes. Therefore, natural polymer chitosan (CS) and synthetic polymer poly(vinyl alcohol) (PVAL) have drawn considerable attention. ${ }^{3-6} \mathrm{CS}$ is the second most abundant natural biopolymer obtained by chitin alkaline deacetylation. Due to its low cost production, natural abundance and eco-compatibility, CS is the preferred bio-material membrane for ultra-filtration, reverse-osmosis and pervaporation. ${ }^{3,7,8}$ PVAL is also an attractive material for membrane electrolyte development as it is a cheap polymer holding high density functional - $\mathrm{OH}$ groups with potential for chemical crosslinking. ${ }^{9-11}$ These polymers show good film forming properties, chemical resistance and the hydrophilic group high density allows chemical modifications of the polymer chain by crosslinking and grafting. ${ }^{11,12}$

* e-mail: paula_qme@yahoo.com.br
Literature sustains that PVAL, CS and PVAL/CS blends in membrane forms have been reported by several researchers and used for some applications, e.g. in selective membranes and in ion exchange membranes..$^{13,14}$ Mobarak et al. ${ }^{15}$ synthesized carboxymethyl chitosan membranes, by a solution-casting technique, for polymer electrolyte applications. Modified chitosan membranes presented amorphous properties and an ionic conductivity two orders of magnitude higher when compared to a pure chitosan membrane. Polymer electrolyte membranes for fuel cell applications were prepared using sulfonated PVAL synthesized from 4-formylbenzene1,3-disulfonic acid and subsequently cross-linked with 1,3-bis(3-glycidyloxypropyl) tetramethyldisiloxane and 4,4'-oxydiphthalic anhydride. Such membranes presented good proton conductivity $\left(0.218 \mathrm{~S} \mathrm{~cm}^{-1}\right.$ at $\left.70^{\circ} \mathrm{C}\right)$ and low methanol permeability (at around $1.25 \times 10^{-6} \mathrm{~cm}^{2} \mathrm{~s}^{-1}$ ), thus, suggesting that the membranes can be used in a direct methanol fuel cell (DMFC). ${ }^{16}$ Ceramic-supported PVAL-CS composite membranes were also prepared for pervaporation dehydration purposes. Authors observed that the surface hydrophilicity decreased with chitosan content. ${ }^{17}$ Zang et al. ${ }^{18}$ prepared composite membranes comprising Nafion, chitosan and poly(vinyl alcohol) for DMFC. PVAL/CS membranes were used as a substrate while Nafion was used as a filling polymer. The electrostatic interaction between Nafion (polyanion) and CS (polycation) improved proton conductivity by 17 times when compared with PVAL/CS membrane.

Nylon presents characteristic amide groups in the backbone chain, being also called polyamide. Polar amide groups are able to form hydrogen bonds with other polymers and the polymer backbone itself, thus increasing polymer crystallinity. These characteristics can improve composite 
properties when blending nylon with other polymers, as described by Lu et al. ${ }^{19}$ Chitosan/nylon 6,6 blends crosslinked with sulphuric acid were studied by Smitha et al. ${ }^{20}$, who have evaluated physical-mechanical properties and their efficiency in a dioxane-water mixture dehydration. These blends presented good mechanical properties with improved stability in aqueous solutions; blends have also showed good selectivity to dioxane/water mixture. ${ }^{20}$ In the present work, nylon 6,6 was used to reduce the excessive swelling of the prepared polymer electrolyte membranes, consequently improving their mechanical properties.

Literature presents scarce studies on membranes prepared from the blend of sulphonated PVAL/CS acting as a methanolbarrier. Hence, this study proposes the application of PVAL/ CS membranes containing sulphonic acid groups with and without nylon 6,6 in a fuel cell, using hydrogen and methanol. Therefore, the prepared membranes were characterized by infrared spectroscopy, thermal gravimetric analysis (TGA), dynamical mechanical (DMA), water uptake and proton conductivity tests, followed by PEMFC and DMFC tests.

\section{Experimental}

\subsection{Materials}

Poly(vinyl alcohol) (PVAL) (99\% hydrolysed with a molecular weight of 89,000 to $\left.98,000 \mathrm{~g} \mathrm{~mol}^{-1}\right)$, chitosan flakes with high molecular weight, Nylon 6,6 and sulfosuccinic acid (SSA, 70\% aqueous solution) were supplied by Sigma Aldrich Chemical Co. The solvent formic acid was purchased from Fisher Scientific. Polymers and acid structures used are shown in Figure 1.

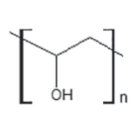

(A)<smiles>CC(=O)CCCCC(=O)NNCCCCCCN1CCC1</smiles>

(C)

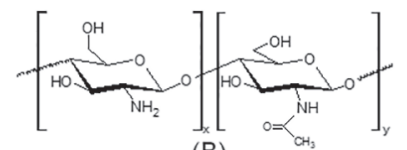

(B)

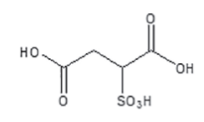

(D)

Figure 1: Monomeric unit of polymers and acid structures: (A) PVAL, (B) CS, (C) nylon 6,6 and (D) SSA.

\subsection{Membrane preparation}

$10_{\mathrm{wt}}^{\%}$ PVAL and $1_{\mathrm{wt}} \% \mathrm{CS}$ aqueous solutions were prepared by dissolving the dry polymers in aqueous formic acid solution $(50 / 50, \mathrm{w} / \mathrm{w})$. Two polymer blends of PVAL/ CS, 60/40 and 80/20 (w/w) were prepared. The blends were stirred for $2 \mathrm{~h}$ and SSA was added according to $16 / 1$, $8 / 1$ and 4/1 molar ratios, corresponding to the polymeric unit in the blend/SSA molar ratio. Final solutions were stirred for at least $24 \mathrm{~h}$ at room temperature, casted on a polystyrene plate and homogeneous membranes were obtained after solvent evaporation, at room temperature. Membranes were maintained at $100{ }^{\circ} \mathrm{C}$ for $1.5 \mathrm{~h}$ to promote the crosslinking reaction in a vacuum oven. Nylon 6,6 addition to the blends was performed by preparing a $1 \mathrm{wt} \%$ nylon solution in pure formic acid dropped to the PVAL/CS/SSA mixture two hours before completing the $24 \mathrm{~h}$ stirring time as described above. The amount of Nylon solution added corresponded to a $1 \%$ mass fraction in relation to the polymer blend PVAL/CS. Membranes were further prepared as described above. Membrane chemical composition and their code are showed in Table 1.

Table 1: Chemical composition and molar ratio between monomeric unit and SSA.

\begin{tabular}{lccc}
\hline Membrane code & $\begin{array}{c}\text { PVAL/CS } \\
(\mathrm{w} / \mathrm{w})\end{array}$ & $\begin{array}{c}\text { Blend/SSA } \\
(\mathrm{mol} / \mathrm{mol})^{\mathrm{a}}\end{array}$ & Nylon (wt \%) \\
\hline $80 \_16 / 1$ & $80 / 20$ & $16 / 1$ & - \\
$80 \_16 / 1$ Nylon & $80 / 20$ & $16 / 1$ & 1 \\
$80 \_8 / 1$ & $80 / 20$ & $8 / 1$ & - \\
$80 \_8 / 1$ Nylon & $80 / 20$ & $8 / 1$ & 1 \\
$80 \_4 / 1$ & $80 / 20$ & $4 / 1$ & - \\
$80 \_4 / 1$ Nylon & $80 / 20$ & $4 / 1$ & 1 \\
$60 \_16 / 1$ & $60 / 40$ & $16 / 1$ & - \\
$60 \_16 / 1$ Nylon & $60 / 40$ & $16 / 1$ & 1 \\
$60 \_8 / 1$ & $60 / 40$ & $8 / 1$ & - \\
$60 \_8 / 1$ Nylon & $60 / 40$ & $8 / 1$ & 1 \\
$60 \_4 / 1$ & $60 / 40$ & $4 / 1$ & - \\
$60 \_4 / 1$ Nylon & $60 / 40$ & $4 / 1$ & 1 \\
\hline
\end{tabular}

\subsection{Characterization}

Attenuated total reflection Fourier infrared (ATR-FTIR) spectra were recorded on a Nicolet IS $10 \mathrm{MX}$ infrared spectrophotometer equipped cooled mercury-cadmium telluride detector (MCT). The internal reflection element was a germanium crystal and 16 scans were averaged for each spectrum at a resolution of $4 \mathrm{~cm}^{-1}$.

Membrane thermal stability was evaluated using a thermogravimetric analyser (TGA) (TG209 F1 Netzch). A constant temperature ramp rate of $10{ }^{\circ} \mathrm{C} \mathrm{min}-1$ from room temperature up to $700^{\circ} \mathrm{C}$, under inert gas flow was applied. Before the analysis, membranes were maintained under vacuum for $24 \mathrm{~h}$ at $30{ }^{\circ} \mathrm{C}$ to remove absorbed water.

\subsection{Water Uptake}

Membrane sorption capacity was measured by immersing membrane samples into water at room temperature. First, samples were dried in a vacuum oven at room temperature until a constant weight, immersed into water for $24 \mathrm{~h}$ and wiped with a cleansing paper, and weighed quickly. This procedure was repeated until obtaining a satisfactory reproducibility. The swelling degree, $Q$, was calculated as follows (Equation 1):

$$
Q=\left(\frac{m-m_{0}}{m_{0}}\right) \times 100
$$

where $m$ is the mass of the swollen sample and $m_{0}$ is the original mass. 


\subsection{Dynamic mechanical analysis (DMA)}

Dynamic mechanical analysis was performed using a DMA Q800-TA. Initially, membranes of PVAL/CS_SSA with and without nylon, $0.53 \mathrm{~mm}$ wide, were equilibrated at $100 \%$ relative humidity for $24 \mathrm{~h}$. On the tensile deformation tests, samples were kept at $50{ }^{\circ} \mathrm{C}$ for $2 \mathrm{~min}$ and then submitted to $0.01 \mathrm{~N} \mathrm{~s}^{-1}$ rate strength, in which the maximum force applied was $18 \mathrm{~N}$. The Young's modulus and the elastic strain were computed based on the strain and stress values obtained from average of three determinations for each membrane formulation.

\subsection{Ion exchange capacity (IEC)}

Membrane ion exchange capacity was determined through acid-base titration. The acidic dry membrane was immersed into $20 \mathrm{~mL}$ of saturated sodium chloride aqueous solution for $24 \mathrm{~h}$ in order to exchange protons for sodium ions. The released acid was subsequently titrated using a $0.01 \mathrm{~mol} \mathrm{~L}^{-1}$ sodium hydroxide standardized solution and the indicator phenolphthalein. IEC $\left(\mathrm{mmol} \mathrm{g}^{-1}\right)$ was calculated using equation 2 :

$$
I E C=\frac{M \times V}{W_{\text {dry }}}
$$

where $M$ is the concentration of the titrant $\left(\mathrm{mmol} \mathrm{mL}^{-1}\right)$, $V$ is the added volume of titrant at the equivalent point $(\mathrm{mL})$ and $W_{\text {dry }}$ is the sample dry mass (g).

\subsection{Fuel cell tests}

PVAL/CS membranes with different sulfonation degrees were sandwiched between Toray carbon papers loaded with a catalyst considering the effective area of $4.84 \mathrm{~cm}^{2}$, using a Pt loading of $0.5 \mathrm{mg}_{\mathrm{pt}} \mathrm{cm}^{-2}\left((10 \mathrm{wt} . \% \mathrm{Pt}) / \mathrm{Vulcan}^{\circledR}\right.$, ElectroChem SA) at the anode and the cathode. PEMFC was operated at $50^{\circ} \mathrm{C}$ with a feed flow rate of $200 \mathrm{~mL} \mathrm{~min}^{-1}$ of hydrogen at $1 \mathrm{bar}$ and $400 \mathrm{~mL} \mathrm{~min}{ }^{-1}$ of air at 1 bar; the relative humidity used during the tests was $75 \%, 90 \%$ and $100 \%$. Membranes were characterized by electrochemical impedance spectroscopy (EIS) and polarization curves. Each polarization curve was obtained in potentiostatic mode, starting at $\mathrm{OCV}$ and decreasing the potential. $\mathrm{AC}$ impedance spectroscopy was obtained in the frequency range from $100 \mathrm{kHz}$ to $100 \mathrm{mHz}$ with a $5 \mathrm{mV}$ perturbation amplitude using a Zahner IM6e electrochemical workstation coupled with a potentiostat PP-241. The proton conductivity (s) was obtained using the following equation 3 :

$$
\sigma=\frac{l}{R \cdot S}
$$

where $\mathrm{s}$ is the proton conductivity $\left(\mathrm{S} \mathrm{cm}^{-1}\right), l$ is the distance between the electrodes ( membrane thickness, $\mathrm{cm}$ ), $R$ is membrane resistance (W), and $S$ is the surface area required for a proton penetrating the membrane (electrode area) $\left(\mathrm{cm}^{2}\right)$.

Membranes with the best mechanical properties and proton conductivity were further tested in a direct methanol fuel cell. Thus, membranes were sandwiched between
Toray carbon papers loaded with catalyst considering the effective area of $4.84 \mathrm{~cm}^{2}$. Pt was used as a catalyst on the cathode $\left(0.5 \mathrm{mg}_{\mathrm{Pt}} \mathrm{cm}^{-2}(10 \mathrm{wt} \%\right.$ Pt $) /$ Vulcan ${ }^{\circledR}$, ElectroChem, SA) and Pt:Ru on the anode (1.0 $\mathrm{mg}_{\mathrm{Pt}: \mathrm{Ru}} \mathrm{cm}^{-2}$ ( 20 wt. $\%$ $\mathrm{PtRu}(1: 1 \mathrm{Pt}: \mathrm{Ru}) / \mathrm{Vulcan}^{\circledR}$, ElectroChem, SA). DMFC tests were performed at $50^{\circ} \mathrm{C}$ with a $2 \mathrm{~mL} \mathrm{~min}^{-1}$ feed flow rate of methanol solution $\left(2 \mathrm{~mol} \mathrm{~L}^{-1}\right)$ on the anode and $300 \mathrm{~mL}$ $\mathrm{min}^{-1}$ of oxygen on the cathode at $100 \%$ of relative humidity. Fuel cell characterization was performed as described above.

Linear sweep voltammetry (LSV, scan rate of $5 \mathrm{mV}$ $\min ^{-1}$ ) was employed to evaluate hydrogen and methanol crossover. Therefore, hydrogen or $2 \mathrm{M}$ methanol solution were fed into the cathode compartment of the electrolytic cell and the cathode served as a reference/counter electrode. In this configuration, hydrogen evolves at the cathode which is being used as a dynamic hydrogen reference electrode (DHE); the same process occurs when methanol is used. On the other hand, nitrogen $\left(2 \mathrm{~L}_{\mathrm{N}} \mathrm{min}^{-1}\right.$, atmospheric pressure $)$ was fed into the anode compartment of the electrolytic cell, serving as a working electrode.

\section{Results and Discussion}

\subsection{Infrared}

Figure 2 shows membrane PVAL/CS_SSA infrared spectra crosslinked at $100{ }^{\circ} \mathrm{C}$ for $1.5 \mathrm{~h}$ in the region $3700-600 \mathrm{~cm}^{-1}$, being (A) the membrane spectra with $80 / 20 \mathrm{PVAL} / \mathrm{CS}$ and (B) the membrane spectra with 60/40 PVAL/CS, both with different SSA amounts. The absorption bands that characterize polymers PVAL and CS are described in Table 2 and can be seen in Figures 2 (A), (B). However, the absorption band intensities are not the same in all spectra since the blends were formed from different polymer quantities. Absorption bands that characterize chitosan in the region $1650-1300 \mathrm{~cm}^{-1}$ can be observed pre-eminently in the membrane spectra formed from the blend 60/40 (PVAL/CS) (Figure 2 (B)).

The absorption band of esters (-COO-) is at 1725 $\mathrm{cm}^{-1}$ and can be observed in Figure 2A, denoting that the crosslinking reaction involving the hydroxyl group from PVAL or CS and SSA has occurred. This absorption band intensity increases with SSA concentration in the molar range of 16/1, 8/1 and 4/1 (polymer monomeric unit/SSA). The absorption band at $1235 \mathrm{~cm}^{-1}$ is related to C-O ester group stretching mode and also increases with the polymer monomeric unit/SSA ratio (Figure 2A). However, a small absorption band dislocation was observed, $1718 \mathrm{~cm}^{-1}$ and $1220 \mathrm{~cm}^{-1}$, respectively, when the membranes formed from the $60 / 40$ (PVAL/CS) blends and SSA were analysed (Figure $2 \mathrm{~B})$. This is probably related to the higher amount of CS in the blend and consequently to an increased amino group content. These amino groups react with SSA, forming the amide group, causing a band shift to lower wavenumbers. It is possible to identify the absorption bands that indicate the reaction between SSA and the amino groups: at $1640 \mathrm{~cm}^{-1}$ in the $80 / 20$ blend (Figure 2A) and at a higher intensity, 1630 $\mathrm{cm}^{-1}$, for the $60 / 40$ blend. When increasing SSA content, absorption bands in the region $3500-3200 \mathrm{~cm}^{-1}$ show lower intensities, since the reaction between the hydroxyl and the amino groups with SSA reduces these free groups in 


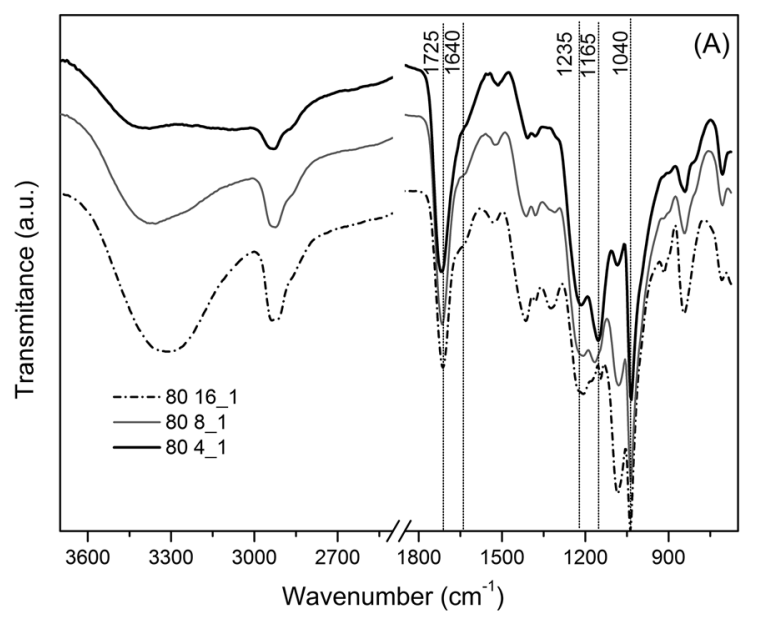

Figure 2: Infrared spectra of blends PVAL/CS, 80/20 (A) and 60/40 (B), with SSA in the indicated ratio, in the region of $3700-650 \mathrm{~cm}^{-1}$.

Table 2: IR bands of polymers PVAL ${ }^{11}, \mathrm{CS}^{21}$ and Nylon $66^{22}$ and compound $\mathrm{SSA}^{23}$ :

\begin{tabular}{|c|c|c|}
\hline Sample & IR band $\left(\mathrm{cm}^{-1}\right)$ & Description* \\
\hline \multirow{5}{*}{ PVAL } & 3300 & $v(-\mathrm{OH})$ \\
\hline & 2940 & $v\left(-\mathrm{CH}_{2}\right)$ \\
\hline & 1433 & $v_{\mathrm{as}}(\mathrm{C}-\mathrm{H})$ \\
\hline & 1140 & $\begin{array}{l}v(\mathrm{C}-\mathrm{O}) \text { and } v(\mathrm{C}-\mathrm{C}) \\
\text { (crystallinity degree) }\end{array}$ \\
\hline & 1096 & $v(\mathrm{C}-\mathrm{O})$ \\
\hline \multirow{9}{*}{ CS } & $3750-3000$ & $\begin{array}{c}v(\mathrm{O}-\mathrm{H}) \text { overlapped to the } \\
v_{\mathrm{s}}(\mathrm{N}-\mathrm{H})\end{array}$ \\
\hline & 2920 and 2875 & $v_{\text {as }}(\mathrm{C}-\mathrm{H})$ and $v_{\mathrm{s}}(\mathrm{C}-\mathrm{H})$ \\
\hline & 1660 & $v(\mathrm{C}=\mathrm{O})$ secondary amide \\
\hline & 1553 & $v\left(-\mathrm{NH}_{3}^{+}\right)$protonated amine \\
\hline & 1420,1376 & $v(\mathrm{C}-\mathrm{H})$ \\
\hline & 1313 & $v_{s}\left(-\mathrm{CH}_{3}\right)$ tertiary amide \\
\hline & 1260 & $v(\mathrm{C}-\mathrm{O}-\mathrm{H})$ \\
\hline & $1156,1065,1026$ & $v_{\text {as }}(\mathrm{C}-\mathrm{O}-\mathrm{C})$ and $v_{\mathrm{s}}(\mathrm{C}-\mathrm{O}-\mathrm{C})$ \\
\hline & 890 & $v(\mathrm{C}-\mathrm{H})$ \\
\hline \multirow{5}{*}{ Nylon 66} & 3300 & $v(\mathrm{~N}-\mathrm{H})$ \\
\hline & 3080 & $v_{s}(\mathrm{~N}-\mathrm{H})$ \\
\hline & 1640 & $v(\mathrm{C}=\mathrm{O})$ amide $\mathrm{I}$ \\
\hline & 1540 & $v(\mathrm{C}-\mathrm{N})$ and $v_{\mathrm{as}}(\mathrm{CO}-\mathrm{N}-\mathrm{H})$ \\
\hline & 940 & $v(\mathrm{C}-\mathrm{CO})$ \\
\hline \multirow{8}{*}{ SSA } & $3200-3600$ & $\begin{array}{c}v(\mathrm{O}-\mathrm{H}) \text { from }-\mathrm{SO}_{3} \mathrm{H}, \mathrm{COOH} \\
\text { and free water }\end{array}$ \\
\hline & $2800-2900$ & $v_{a s}(\mathrm{C}-\mathrm{H})$ and $v_{\mathrm{s}}(\mathrm{C}-\mathrm{H})$ \\
\hline & 1724 & $v(\mathrm{COCH})$ \\
\hline & 1632 & $v(-\mathrm{OH})$ \\
\hline & $1300-1500$ & $v(\mathrm{C}-\mathrm{H})$ \\
\hline & 1167 & $v_{\text {as }}(\mathrm{O}=\mathrm{S}-\mathrm{O})$ \\
\hline & 1041 & $v_{\mathrm{s}}(\mathrm{S}-\mathrm{O})$ \\
\hline & 860 & $v(\mathrm{C}-\mathrm{H})$ \\
\hline
\end{tabular}

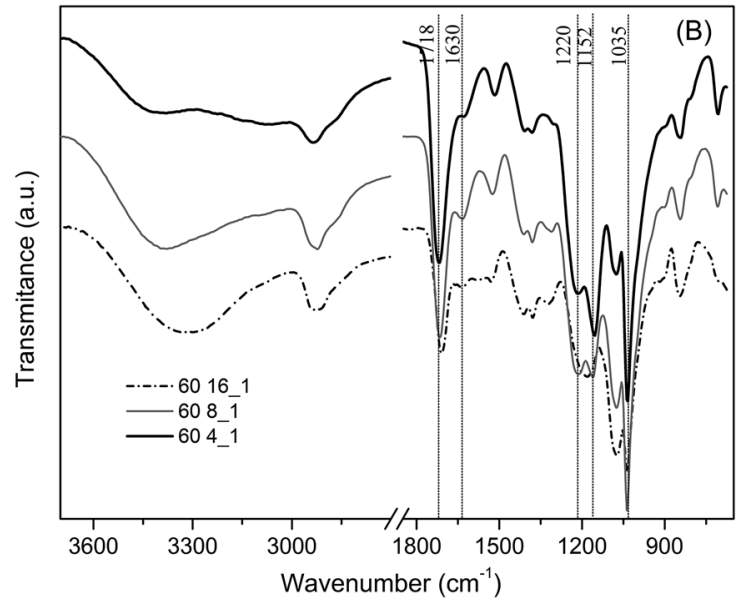

the polymer. The absorption band around $1040 \mathrm{~cm}^{-1}$ results from symmetric S-O stretching and can be observed in the spectra of both blends and is due to SSA in the membranes.

The addition of nylon has not promoted any visible changes in the membrane infrared spectra, probably, due to the low quantity of nylon used. Moreover, nylon presents absorption bands that overlap CS absorption bands, as observed in Table 2.

\subsection{Thermal properties}

Thermal stability of PVAL/CS_SSA and PVAL/ CS_SSA/Nylon membranes was studied by TGA (Figures $3,4)$. Thermograms of PVAL/CS/SSA blends show several decomposition steps, better appreciated in the derivative thermogravimetry (DTG) plots inserted into the TG plots. The main degradation stages occur due to dehydration, degradation and decomposition of polymeric backbone and blend. ${ }^{4,6,24}$ Thermal degradation starts at $140{ }^{\circ} \mathrm{C}$ for lower CS content membranes (Figure 3 (A)). DTG (Figure 3 (A)) shows that SSA crosslink interferes directly with membrane degradation process. Membranes with a larger concentration of CS (Figure 3 (B)) present best stability and polymer degradation only starts after $190{ }^{\circ} \mathrm{C}$, with the exception of membrane 60_4/1. This exception occurred, probably, due to the high SSA content in the membrane, which can induce membrane degradation at lower temperatures. ${ }^{6}$

Figure 4 (A) shows that the nylon in 80/20 (PVAL/CS) blends improved thermal stability of all the membranes tested. For 60/40 (PVAL/CS) blends, thermal stability of all membranes was not affected by nylon (Figure 4 (B)). In the DTG graphics inserted in Figure 4 (A), (B) the initial temperature for membrane degradation can be accurately observed.

\subsection{Water Uptake, Mechanical Properties and Ion Exchange Capacity (IEC)}

PVAL has a large density of hydrophilic groups $-\mathrm{OH}$ in the polymeric chain that can absorb water. Therefore, 

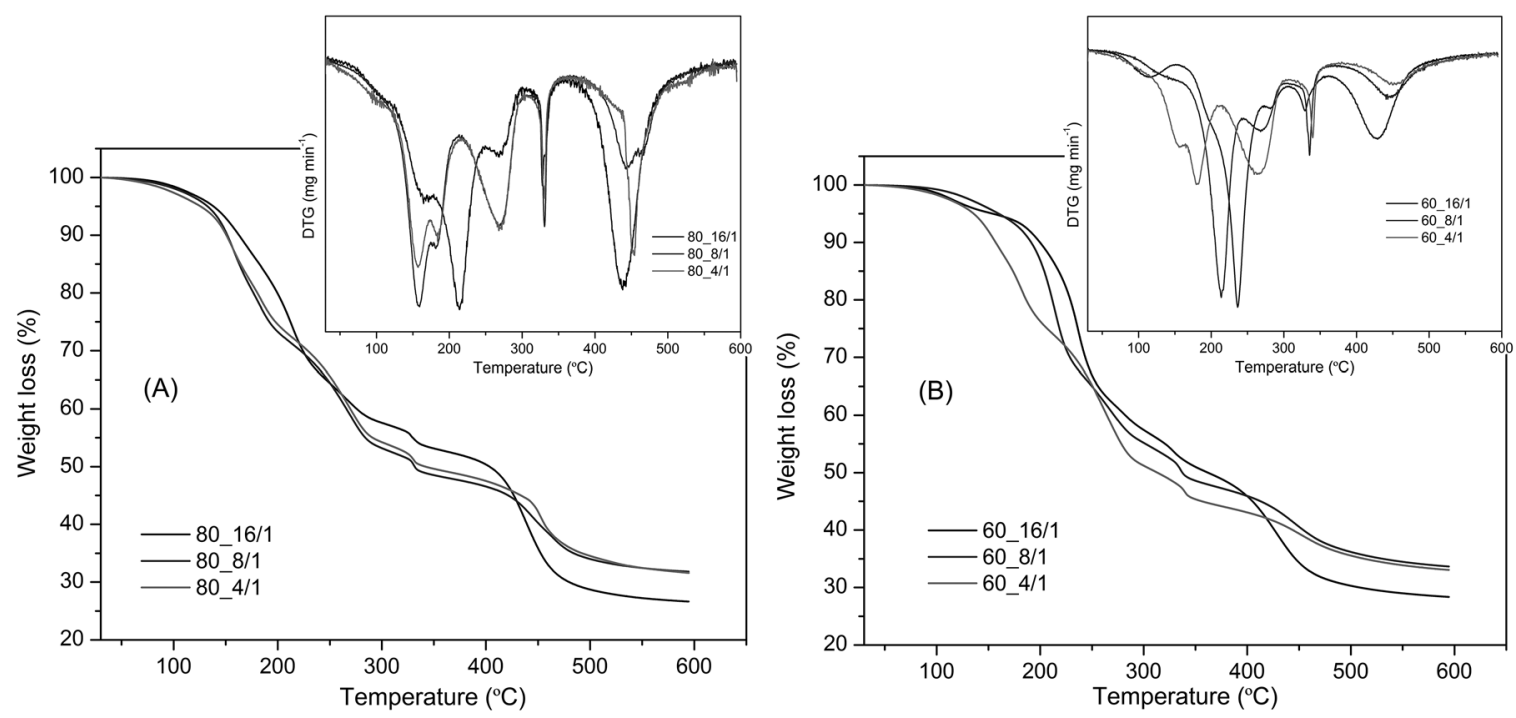

Figure 3: TG thermograms for the blends PVAL/CS, 80/20 (A) and 60/40 (B), respectively, with SSA in the proportion indicated inside the plots.
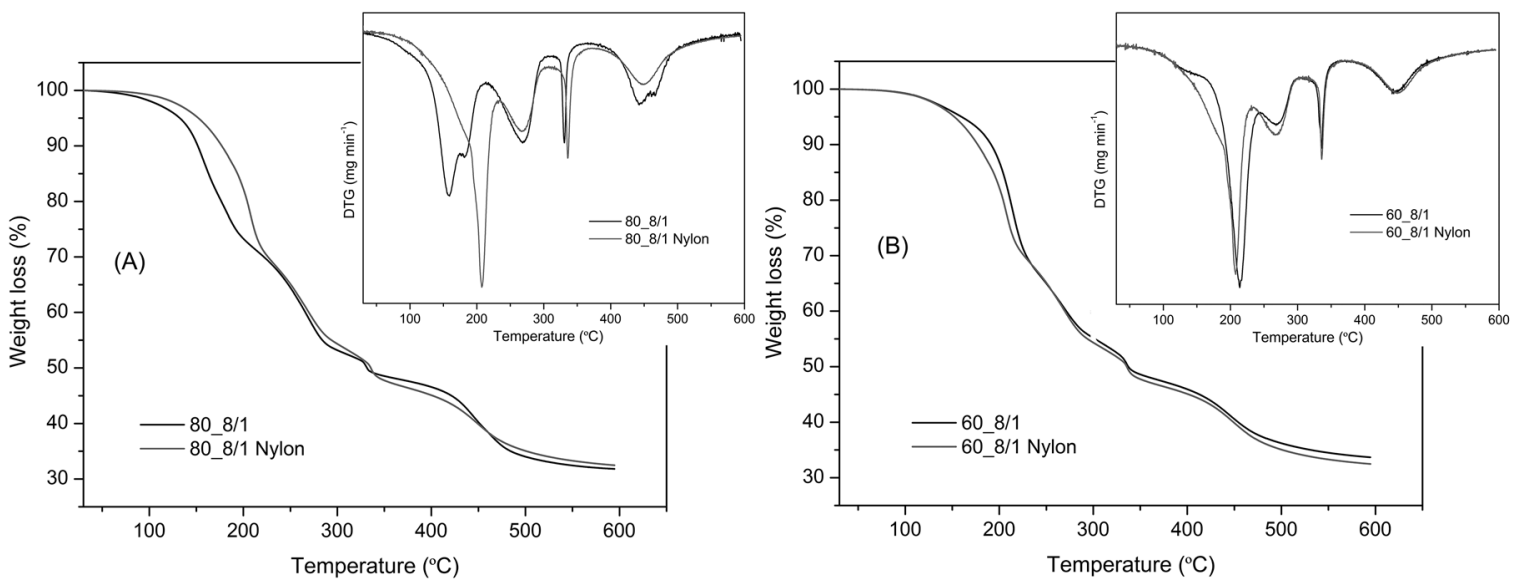

Figure 4: Comparison between TG thermograms for the blends PVAL/CS, 80/20 (A) and 60/40 (B), respectively, with the proportion of $8 / 1$ of SSA and with or without nylon addition.

membranes with a higher content of PVAL, absorbed more water (80/20 blends) than the lower PVAL content blends (60/40) (Figure 5). CS has two hydrophilic groups in its chain (-OH and -NH3) but the most part of its chain presents hydrophobic properties. Therefore, increasing SSA content in the blends increases the hydrophilic groups. On the other hand, the rise of crosslinking degree occurs. Moreover, 80/20 blends (80_16/1 and 80_8/1) water uptake decreases as SSA concentration increases, probably due to the rise of crosslinking degree, which consumes free -OH groups. Contrarily, membrane $80 \_4 / 1$, with the highest SSA content, presents a water uptake similar to membrane $80 \_8 / 1$. In this case, the crosslinking reaction effect is probably compensated by the presence of SSA hydrophilic groups. Concerning 60/40 blends, it can be suggested that CS interacts by hydrogen bonding with PVAL, decreasing the free volume of the polymeric membranes. This causes a more rigid structure and decreases water uptake. Results have also shown that the addition of SSA to $60 / 40$ blends may interfere with the
PVAL/CS interaction, and as SSA has hydrophilic groups the membranes absorb more water. However, with the presence of higher SSA contents the crosslinking density increases and the free volume in the polymeric structure reduces, this resulting in a decrease of water molecule mobility and consequently less water is uptaken.

Nylon induced two different effects in membrane water uptake (Figure 6); 60/40 blends with Nylon showed a slightly increase in water absorption, probably due to the changing operated by Nylon in the interaction between the PVAL and CS or/and between PVAL/CS and SSA. For 80/20 blends, nylon addition decreased water uptake, most likely to its easy interaction with the free-OH from PVAL, decreasing the number of $-\mathrm{OH}$ able to take up water in the membranes. The interaction among the polymers can also decrease membrane free volume, thus becoming more difficult for water diffusion.

Membrane mechanical properties were evaluated by tensile tests using DMA (Table 3). Membranes prepared 


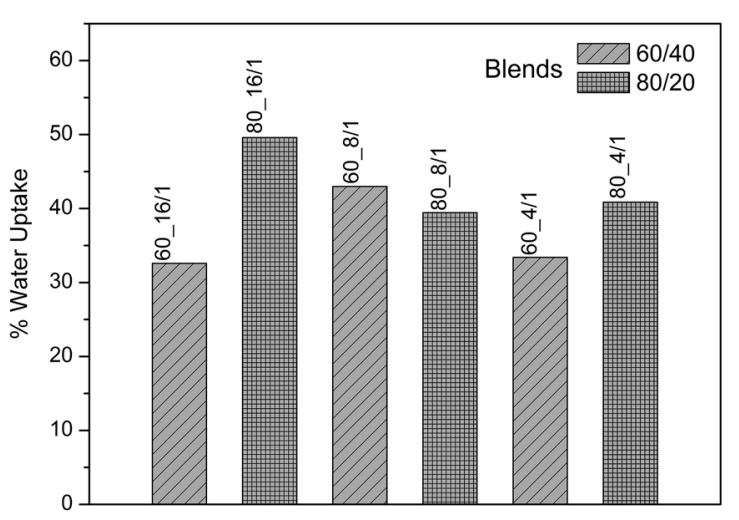

Figure 5: Water uptake percentage to blends $60 / 40$ and $80 / 20$ with different SSA ratios.

with PVAL/CS and SSA are in general stiff, as the crosslink promoted by SSA restricts chain segmental mobility. The addition of nylon caused a decrease in the Young's modulus $(E)$ and an increase in the elastic strain $\left(\varepsilon_{e}\right)$, possibly, related to nylon plasticizer behaviour, facilitating the movement among the chains. This plasticizer action was more pronounced on the 60/40 blends, where the Young's modulus decreased significantly with nylon addition. These results confirm the greater interaction between nylon and the 80/20 (PVAL/CS) blends, as explained above. The results of elastic strain $\left(\varepsilon_{e}\right)$, showed in the Table 3, corroborate with the Young's modulus results and confirm the plasticizer action of Nylon in the membranes. Figure 7 shows a representative tensile test curves for each blend studied.

IEC indicates the density of ionisable hydrophilic groups in the polymer matrix which is responsible for membrane ionic conductivity. IEC increased with SSA content, from 1.1 to $3.92 \mathrm{mmol} \mathrm{g}^{-1}$ in the 60/40 (PVAL/ CS) blend and from 1.56 to $3.99 \mathrm{mmol} \mathrm{g}^{-1}$ in the $80 / 20$ blends. This is related to the sulfonic acid group in SSA (Table 3). All the blends presented an IEC value higher than the one obtained for Nafion ${ }^{\circledR} 115,0.91 \mathrm{mmol} \mathrm{g}^{-1}$. On the other hand, blends prepared with nylon presented an IEC slightly higher than those without nylon, but this result is probably due to the residual solvent, pure formic acid, used to prepare the nylon solution,

\subsection{Fuel cell tests}

PVAL/CS_SSA and PVAL/CS_SSA/Nylon membranes were tested in a fuel cell using $\mathrm{H}_{2} / \mathrm{O}_{2}$. Proton conductivity, permeability and I/V curves were obtained and data are shown in Table 4. Results are presented only for membranes that have showed to be stable under fuel cell conditions. According to that, 60/40 (PVAL/CS) membranes showed low stability inside the fuel cell and only membranes 60_4/1 and 60_4/1 nylon were tested. Nylon decreased proton conductivity on the membranes with a $4 / 1$ monomeric unit/SSA molar ratio. The standard membrane, Nafion ${ }^{\circledR} 115$, under the same conditions (90 $\%$ relative humidity), presented a proton conductivity of $5.7 \times 10^{-2} \mathrm{~S} \mathrm{~cm}^{-1}, 6$ 80/20 membranes showed an increasing in the proton conductivity with the rise of acid content and humidity level. These membranes have shown proton conductivity similar to some results found in the literature for membranes using PVAL or CS..$^{4,5,11,18}$ Proton conductivity results are in agreement with IEC values, both increased with SSA quantity.

Hydrogen permeability increased with nylon in both cases. This suggests that polar molecules had some difficulty passing through the membrane structure formed with PVAL, $\mathrm{CS}$ and nylon (eg. water, as mentioned above) and that the nonpolar molecules $\left(\mathrm{H}_{2}\right)$ passed easily through the same structure. Permeability to hydrogen is shown in Table 4. These values were lower than the corresponding ones for the Nafion ${ }^{\circledR} 115$ membrane, $8.33 \times 10^{-12} \mathrm{~mol} \mathrm{~cm} \mathrm{bar}^{-1} \mathrm{~s}^{-1} \mathrm{~cm}^{-2}$, under the same conditions. ${ }^{6}$

PEMFC performance employing PVAL/CS/SSA and PVAL/CS/SSA_Nylon membranes was studied (Table 5). Membrane 80_4/1 showed the best performance in the fuel cell environment, followed by 60_4/1 Nylon. Membranes formed from the 80/20 (PVAL/CS) blends presented better performance than the corresponding 60/40 (PVAL/CS) blends. Moreover, increasing relative humidity augmented peak power density for most of the membranes tested. In a previous study, membranes using PVAL/SSA loaded with boehmite nanoparticles had shown a PEMFC performance, on average, twice better than the membranes currently analysed. ${ }^{6}$ This probably happened due to the presence of the hydrophobic CS and nylon, in the current work, decreasing proton transport.
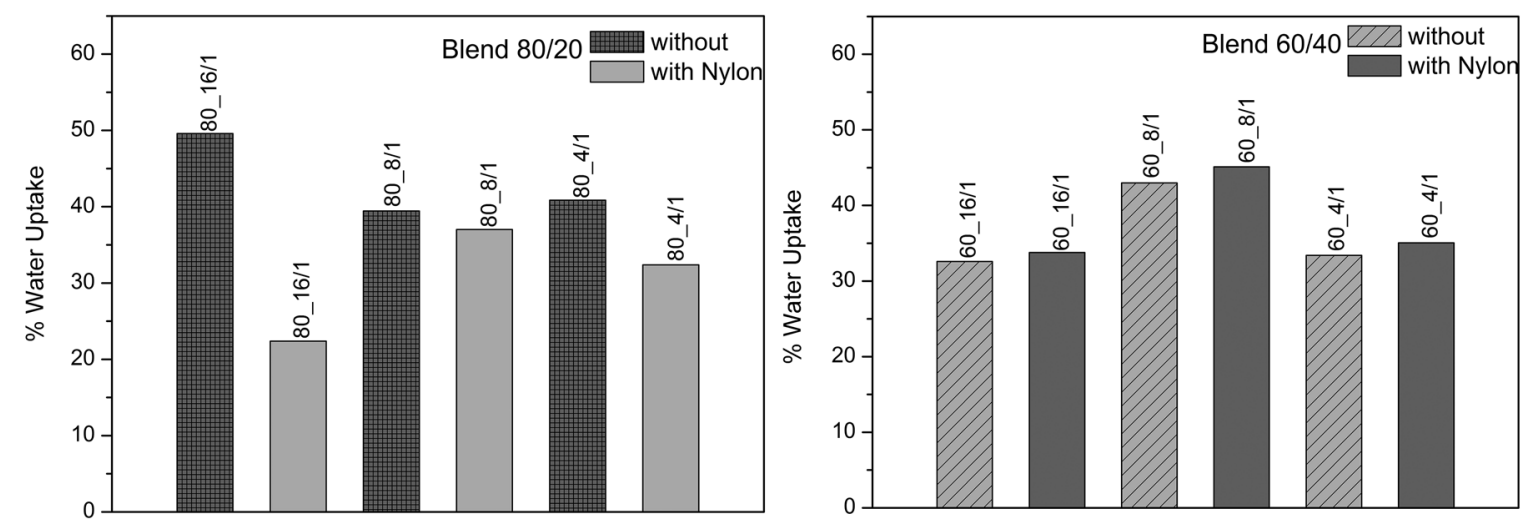

Figure 6: Water uptake percentage to blends $80 / 20$ and 60/40, without and with nylon, with different SSA ratios. 
Table 3: Water uptake, Young's Modulus (E), elastic strain $\left(\varepsilon_{\mathrm{e}}\right)$ and ion exchange capacity (IEC) to analysed membranes.

\begin{tabular}{lcccc}
\hline Membrane code & Water uptake $(\%)$ & $E(\mathrm{MPa})$ & $\varepsilon_{\mathrm{e}}(\%)$ & IEC $\left(\mathrm{mmol} \mathrm{g}^{-1}\right)$ \\
\hline $60 \_16 / 1$ & $32.60 \pm 1.03$ & $2.589 \pm 0.04$ & $2.35 \pm 0.10$ & $1.10 \pm 0.11$ \\
$60 \_16 / 1$ Nylon & $33.78 \pm 3.14$ & $0.788 \pm 0.02$ & $2.65 \pm 0.07$ & $1.32 \pm 0.03$ \\
$60 \_8 / 1$ & $42.99 \pm 2.87$ & $1.281 \pm 0.02$ & $1.21 \pm 0.02$ & $2.72 \pm 0.04$ \\
$60 \_8 / 1$ Nylon & $45.12 \pm 1.33$ & $0.642 \pm 0.05$ & $2.00 \pm 0.10$ & $2.83 \pm 0.03$ \\
$60 \_4 / 1$ & $33.40 \pm 2.62$ & $2.339 \pm 0.04$ & $1.11 \pm 0.06$ & $3.74 \pm 0.15$ \\
$60 \_4 / 1$ Nylon & $35.05 \pm 1.06$ & $0.418 \pm 0.03$ & $2.57 \pm 0.04$ & $3.92 \pm 0.02$ \\
$80 \_16 / 1$ & $49.58 \pm 0.61$ & $2.336 \pm 0.07$ & $2.18 \pm 0.04$ & $1.56 \pm 0.10$ \\
$80 \_16 / 1$ Nylon & $22.39 \pm 1.86$ & $2.268 \pm 0.05$ & $3.08 \pm 0.08$ & $1.92 \pm 0.03$ \\
$80 \_8 / 1$ & $39.43 \pm 3.34$ & $1.960 \pm 0.02$ & $1.76 \pm 0.05$ & $2.26 \pm 0.07$ \\
$80 \_8 / 1$ Nylon & $37.01 \pm 1.86$ & $1.709 \pm 0.05$ & $1.88 \pm 0.11$ & $2.37 \pm 0.02$ \\
$80 \_4 / 1$ & $40.86 \pm 2.56$ & $10.14 \pm 0.15$ & $1.18 \pm 0.04$ & $3.93 \pm 0.15$ \\
$80 \_4 / 1$ Nylon & $32.38 \pm 1.75$ & $3.413 \pm 0.11$ & $1.95 \pm 0.06$ & $3.99 \pm 0.04$ \\
\hline
\end{tabular}
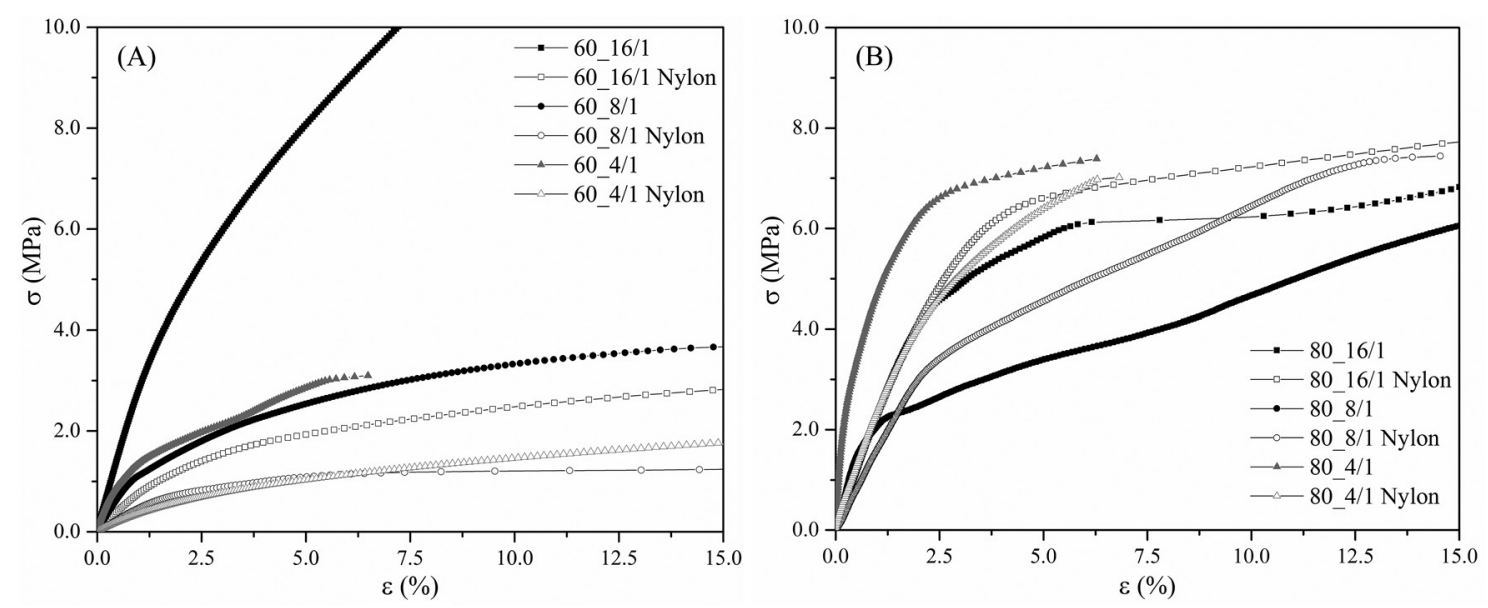

Figure 7: Representative tensile test curves for blends $80 / 20$ and 60/40, without and with nylon, with different SSA ratios.

Table 4: Proton conductivity $(\sigma)$ and permeability $(\rho)$ to fuel measurement in the fuel cell.

\begin{tabular}{|c|c|c|c|c|c|c|}
\hline \multirow[b]{2}{*}{ Membrane code } & \multicolumn{2}{|c|}{$75 \% \mathrm{RH}$} & \multicolumn{2}{|c|}{$90 \% \mathrm{RH}$} & \multicolumn{2}{|c|}{$100 \% \mathrm{RH}$} \\
\hline & $\sigma\left(10^{-2} \mathrm{~S} \mathrm{~cm}^{-1}\right)$ & $\begin{array}{c}\rho\left(10^{-11} \mathrm{~mol} \mathrm{~cm}\right. \\
\left.\operatorname{bar~s}^{-1} \mathrm{~cm}^{-2}\right)\end{array}$ & $\sigma\left(10^{-2} \mathrm{~S} \mathrm{~cm}^{-1}\right)$ & $\begin{array}{c}\rho\left(10^{-11} \mathrm{~mol} \mathrm{~cm}\right. \\
\left.\operatorname{bar~s}^{-1} \mathrm{~cm}^{-2}\right)\end{array}$ & $\sigma\left(10^{-2} \mathrm{~S} \mathrm{~cm}^{-1}\right)$ & $\begin{array}{c}\rho\left(10^{-11} \mathrm{~mol} \mathrm{~cm}\right. \\
\left.\operatorname{bar~s}^{-1} \mathrm{~cm}^{-2}\right)\end{array}$ \\
\hline $60 \_4 / 1$ & 0.583 & 4.507 & - & - & - & - \\
\hline 60_4/1 Nylon & 0.235 & 10.77 & 0.575 & 7.754 & 1.028 & 6.476 \\
\hline 80_16/1 & 0.003 & 3.257 & 0.017 & 3.970 & 0.186 & 20.47 \\
\hline $80 \_8 / 1$ & 0.119 & 3.433 & - & - & - & - \\
\hline 80_4/1 & 0.382 & 4.959 & 0.108 & 4.687 & 1.191 & 5.483 \\
\hline $80 \_4 / 1$ Nylon & 0.242 & 12.89 & - & - & 0.727 & 16.64 \\
\hline
\end{tabular}

* Fuel cell operation temperature of for all the tests was $50{ }^{\circ} \mathrm{C}$.

Membranes 80_4/1 Nylon and 60_4/1 Nylon were also tested in a DMFC environment (Figure 8 ); peak power density was $11.43 \mathrm{~mW} \mathrm{~cm}^{-2}$ and $8.83 \mathrm{~mW} \mathrm{~cm}^{-2}$, respectively. Methanol permeability was very low, $9.92 \times 10^{-11} \mathrm{~mol} \mathrm{~cm} \mathrm{bar} \mathrm{s}{ }^{-1} \mathrm{~cm}^{-2}$ and $6.66 \times 10^{-11} \mathrm{~mol} \mathrm{~cm} \mathrm{bar} \mathrm{s} \mathrm{cm}^{-2}$, respectively. Brandão et al. ${ }^{25}$ tested methanol permeability using the standard Nafion membrane $1135(89 \mathrm{~mm})$, under similar experimental conditions as those used in this study, and a value of $2.00 \mathrm{x}$ $10^{-9} \mathrm{~mol} \mathrm{~cm} \mathrm{bar}^{-1} \mathrm{~cm}^{-2}$ was observed, ca. 100 times higher.
Methanol is a polar molecule and as already mentioned before has difficulty to permeate the membrane. Despite the low methanol permeation obtained, further fuel cell tests are still required in order to optimize membrane electrode assembly fabrication, and accurately determine the performance of these membranes. In practice, membranes described may encounter large interfacial resistance due to the poor adhesion between membranes and catalyzed electrodes, resulting in a poor cell performance, using either $\mathrm{H}_{2}$ or methanol as fuel. 
Table 5: Maximum values to current density $(j)$ and power density $(P)$.

\begin{tabular}{|c|c|c|c|c|c|c|}
\hline \multirow[b]{2}{*}{ Membrane code } & \multicolumn{2}{|c|}{$75 \% \mathrm{RH}$} & \multicolumn{2}{|c|}{$90 \% \mathrm{RH}$} & \multicolumn{2}{|c|}{$100 \% \mathrm{RH}$} \\
\hline & $\begin{array}{c}j \\
\left.(\mathrm{~mA} \mathrm{~cm})^{-2}\right)\end{array}$ & $\begin{array}{c}P \\
\left(\mathrm{~mW} \mathrm{~cm}^{-2}\right)\end{array}$ & $\begin{array}{c}j \\
\left.(\mathrm{~mA} \mathrm{~cm})^{-2}\right)\end{array}$ & $\begin{array}{c}P \\
\left(\mathrm{~mW} \mathrm{~cm}^{-2}\right)\end{array}$ & $\begin{array}{c}j \\
\left.(\mathrm{~mA} \mathrm{~cm})^{-2}\right)\end{array}$ & $\begin{array}{c}P \\
\left(\mathrm{~mW} \mathrm{~cm}^{-2}\right)\end{array}$ \\
\hline $60 \_4 / 1$ & 22.73 & 5.89 & - & - & - & - \\
\hline 60_4/1 Nylon & 67.47 & 17.77 & 118.4 & 30.27 & 177.2 & 54.08 \\
\hline 80_16/1 & 9.067 & 2.203 & 15.89 & 3.590 & 61.67 & 15.28 \\
\hline 80_8/1 & 45.47 & 10.38 & - & - & - & - \\
\hline 80_4/1 & 274.1 & 58.86 & 251.1 & 69.48 & - & - \\
\hline
\end{tabular}

* Fuel cell operation temperature of for all the tests was $50{ }^{\circ} \mathrm{C}$.

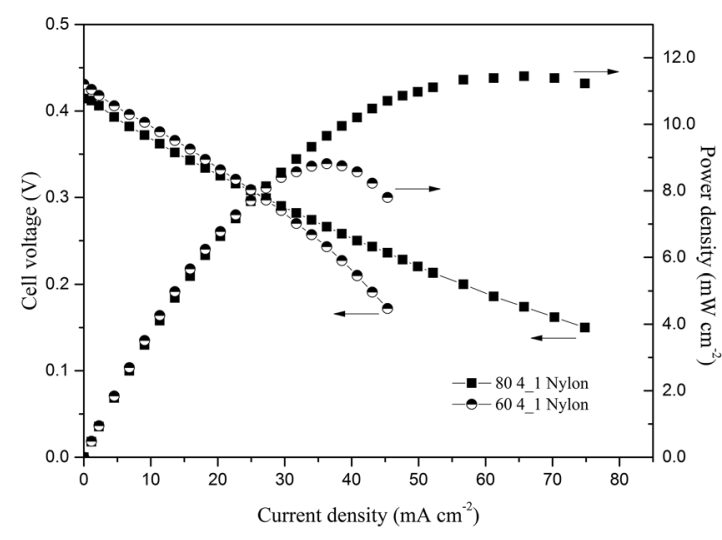

Figure 8: Polarization curves for the DMFC tests using the PVAL/ CS/SSA membranes indicated 80_4/1 Nylon and 60_4/1 Nylon.

\section{Conclusions}

PVAL/CS based membranes were prepared and characterized for fuel cell applications. SSA was used as a crosslinking and a sulfonating agent, acting simultaneously as an inter-crosslinked structure and a sulfosuccinic acid functional group. SSA content increased proton dissociation due to the good connectivity between the ionic sites and the higher density of protogenic groups. Nylon was added to improve the mechanical properties and the results have shown that it had promoted a decreasing in the membrane stiffness. Moreover, as the nylon backbone is formed mostly by hydrophobic molecules, a decrease on methanol permeability in the membranes tested was observed. However, nylon induced a slightly decrease in proton conductivity. This happened probably due to an improvement on polymers interaction, thus narrowing the hydrophilic channel size and hindering proton diffusion. Membranes have showed a quite poor fuel cell performance using $\mathrm{H}_{2}$ and methanol. This problem is probably due to a large interfacial resistance, deriving from a poor adhesion between the catalytic layer and the membranes, resulting in a poor cell performance.

\section{Acknowledgements}

The authors would like to acknowledge the CNPq, Project 'Ciência sem Fronteiras' and FCT Projects PTDC/ CTM/108454/2008 and PTDC/EQU-EQU/104217/2008.

\section{References}

1. Kreuer KD. On the development of proton conducting polymer membranes for hydrogen and methanol fuel cells. Journal of Membrane Science. 2001;185(1):29-39.

2. Bauer F, Denneler S, Willert-Porada M. Influence of temperature and humidity on the mechanical properties of Nafion ${ }^{\circledR} 117$ polymer electrolyte membrane. Journal of Polymer Science Part B-Polymer Physics. 2005;43(7):786-795.

3. Ma J, Sahai Y. Chitosan biopolymer for fuel cell applications. Carbohydrate Polymers. 2013;92(2):955-975.

4. Meenakshi S, Bhat SD, Sahu AK, Sridhar P, Pitchumani S, Shukla AK. Chitosan-polyvinyl alcohol-sulfonated polyethersulfone mixedmatrix membranes as methanol-barrier electrolytes for DMFCs. Journal of Applied Polymer Science. 2012;124(S1):E73-E82.

5. Beydaghi H, Javanbakht M, Amoli HS, Badiei A, Khaniani Y, Ganjali M, et al. Synthesis and characterization of new proton conducting hybrid membranes for PEM fuel cells based on poly(vinyl alcohol) and nanoporous silica containing phenyl sulfonic acid. International Journal of Hydrogen Energy. 2011;36(20):13310-13316.

6. Oliveira PN, Catarino M, Müller CMO, Brandão L, Tanaka DAP, Bertolino JR, et al. Preparation and characterization of crosslinked PVAL membranes loaded with boehmite nanoparticles for fuel cell applications. Journal of Applied Polymer Science. 2014;131(8).

7. Rashid N, Rehman MSU, Han JI. Use of chitosan acid solutions to improve separation efficiency for harvesting of the microalga Chlorella vulgaris. Chemical Engineering Journal. 2013;226:238-242.

8. Musale DA, Kumari A, Pleizier G. Formation and characterization of poly(acrylonitrile)/Chitosan composite ultrafiltration membranes. Journal of Membrane Science. 1999;154(2):163-173.

9. Pivovar BS, Wang Y, Cussler EL. Pervaporation membranes in direct methanol fuel cells. Journal of Membrane Science. 1999;154(2):155-162.

10. Rhim JW, Yeom CK, Kim SW. Modification of poly(vinyl alcohol) membranes using sulfur-succinic acid and its application to pervaporation separation of water-alcohol mixtures. Journal of Applied Polymer Science. 1998;68(11):1717-1723.

11. Tsai CE, Lin CW, Hwang BJ. A novel crosslinking strategy for preparing poly(vinyl alcohol)-based proton-conducting membranes with high sulfonation. Journal of Power Sources. 2010;195(8):2166-2173.

12. Xiang Y, Yang M, Guo Z, Cui Z. Alternatively chitosan sulfate blending membrane as methanol-blocking polymer electrolyte membrane for direct methanol fuel cell. Journal of Membrane Science. 2009;337(1-2):318-323. 
13. Choudhury NA, Ma J, Sahai Y. High performance and eco-friendly chitosan hydrogel membrane electrolytes for direct borohydride fuel cells. Journal of Power Sources. 2012;210: 358-365.

14. Yang JM, Chiu HC. Preparation and characterization of polyvinyl alcohol/chitosan blended membrane for alkaline direct methanol fuel cells. Journal of Membrane Science. 2012;419-420:65-71.

15. Mobarak NN, Ahmad A, Abdullah MP, Ramli N, Rahman MYA. Conductivity enhancement via chemical modification of chitosan based green polymer electrolyte. Electrochimica Acta. 2013;92:161-167.

16. Tseng CY, Ye YS, Kao KY, Joseph J, Shen WC, Rick J, et al. Interpenetrating network-forming sulfonated poly(vinyl alcohol) proton exchange membranes for direct methanol fuel cell applications. International Journal of Hydrogen Energy. 2011;36(18):11936-11945.

17. Zhu Y, Xia S, Liu G, Jin W. Preparation of ceramic-supported poly(vinyl alcohol)-chitosan composite membranes and their applications in pervaporation dehydration of organic/ water mixtures. Journal of Membrane Science. 2010;349(12):341-348.

18. Zhang Y, Cui Z, Liu C, Xing W, Zhang J. Implantation of Nafion ${ }^{\circledR}$ ionomer into polyvinyl alcohol/chitosan composites to form novel proton-conducting membranes for direct methanol fuel cells. Journal of Power Sources. 2009;194(2):730-736.
19. Lu B, Zheng G, Dai K, Liu C, Chen J, Shen C. Enhanced mechanical properties of polyethylene composites with low content of electrospun nylon-66 nanofibers. Materials Letters. 2015;140:131-134.

20. Smitha B, Dhanuja G, Sridhar S. Dehydration of 1,4-dioxane by pervaporation using modified blend membranes of chitosan and nylon 66. Carbohydrate Polymers. 2006;66(4):463-472.

21. Mano JF, Koniarova D, Reis RL. Thermal properties of thermoplastic starch/synthetic polymer blends with potential biomedical applicability. Journal of Materials Science: Materials in Medicine. 2003;14(2):127-135.

22. Zhang H, Li S, White CJB, Ning X, Nie H, Zhu L. Studies on electrospun nylon-6/chitosan complex nanofiber interactions. Electrochimica Acta. 2009;54(24):5739-5745.

23. Gruger A, Régis A, Schmatko T, Colomban P. Nanostructure of Nafion ${ }^{\circledR}$ membranes at different states of hydration: An IR and Raman study. Vibrational Spectroscopy. 2001;26(2):215-225.

24. Witt MA, Barra GMO, Bertolino JR, Pires ATN. C Crosslinked chitosan/poly (vinyl alcohol) blends with proton conductivity characteristic. Journal of the Brazilian Chemical Society. 2010;21(9):1692-1698.

25. Brandão L, Rodrigues J, Madeira LM, Mendes A. Methanol crossover reduction by Nafion modification with palladium composite nanoparticles: Application to direct methanol fuel cells. International Journal of Hydrogen Energy. 2010;35(20):11561-11567. 